\section{Kolerautbruddet i Zimbabwe}

Kolerautbruddet kan komme til å påvirke så mange som 60000 mennesker og kan ha alvorlige, regionale konsekvenser, hevdet Verdens helseorganisasjon (1). Dagen etter denne nyhetsmeldingen sa likevel Robert Mugabe at utbruddet, som har drept over 780 mennesker, var over (2).

Foreløpig har det vært 16000 tilfeller av kolera i Zimbabwe siden august, og mortalitetsraten er fem ganger høyere blant kolerapasienter her enn $i$ andre land.

Utbruddet er hovedsaklig forårsaket av mangel på rent vann og dårlige hygieniske forhold. Mangel på helsetjenester har forverret situasjonen. Halvparten av tilfellene har forekommet i Budiriro, en bydel i Harare. Tilgang på rent vann har vært sporadisk i hovedstaden. Den første uken i desember var det i flere bydeler ingen tilgang på rent vann. I tillegg blir søppel liggende i gatene, og kloakken har flommet over flere steder

Robert Mugabe tok kontroll over vannverket og kloakksystemet i Harare fra lokale opposisjonsmyndigheter for to år siden.

Avisen The Herald, som stort sett støtter Mugabe, sa det var regjeringens feil at vannverket hadde gått tom for kjemikalier til å rense vannsystemet til Harare - kjemikalier som kunne ha blitt transportert fra Sør-Afrika på mindre enn 24 timer.

De to største sykehusene i Harare har stort sett stengt etter at helsepersonell sluttet å komme på jobb. Flere sykehus og skoler står tomme i Zimbabwe. Den høye inflasjonen gjør at lønninger ikke engang dekker transport til og fra jobb. I juli i år steg inflasjonen ifølge offisielle tall over 231 millioner prosent. Men ifølge økonomen John Robertson har inflasjonen nå steget til 8 trillioner prosent.

Verdens helseorganisasjon fryktet i desember at utbruddet i Budiriro kom til å spre seg over jul når folk drar hjem til familie i andre deler av landet. De frykter også at utbruddet kommer til å spre seg til nabolandene. Sør-Afrika har allerede hatt 460 tilfeller av kolera og ni dødsfall, de fleste ved grensen til Zimbabwe.

\section{Oda Riska}

oriska@hotmail.com

Tidsskriftet

\section{Litteratur}

1. Health system problems aggravate cholera outbreak in Zimbabwe. WHO 10.12.2008. www.who.int/mediacentre/news/releases/ 2008/pr49/en/index.html (16.12.2008).

2. Dugger $\mathrm{CW}$. Cholera is raging, despite denial by Mugabe. The New York Times 11.12.2008 www.nytimes.com/2008/12/12/world/africa/ 12cholera.html?_r=2\&partner=rss\&emc=rss (16.12.2008)

\title{
Hvor går norsk innsats i internasjonal helseforskning?
}

Norge er på verdenstoppen når det gjelder utviklingshjelp. Likevel bidrar vi lite til global helseforskning. Regjeringen har nylig trappet opp slik forskning i vesentlig grad. Spørsmålet er hva de nye pengene bør gå til.

Innen internasjonal helseforskning har vi stadig det samme gapet mellom forskning på folkesykdommer som rammer folk i den rike del av verden, og de som rammer fattigere land (10/90-gapet) (1). Selv for Norges vedkommende er bare $5 \%$ av helseforskningsmidlene rettet mot utfordringer i fattige land (2). Dessuten går bare $1,2 \%$ av det norske budsjettet for utviklingshjelp til forskning (1).

\section{Mer internasjonal helseforskning}

Regjeringen har trappet opp den internasjonale helseforskningen. For det første er Global helse-programmet i Forskningsrådet nå omdannet til Global helse- og vaksinasjonsforskning, som består av to delprogrammer: Global helseforskning og Vaksinasjonsforskning. Global helseforskning får 15 millioner kroner årlig frem til 2010 og skal bli et viktig bidrag i den norske innsatsen for å bekjempe fattigdom (3). Vaksinasjonsforskning har tilgjengelig 50 millioner kroner per år i perioden 2006-15, i hovedsak for å bidra til utvikling av nye vaksiner (4). For det andre har Norge økt innsatsen vesentlig til internasjonale organer som Verdens helseorganisasjon (WHO), Verdensbanken og Bill Gatesfondet. Den største norske satsingen på internasjonal helse går her. Vi er med i den globale vaksinasjonsalliansen GAVI, der Norge skal bidra med 500 millioner kroner årlig i årene 2006-15 (5). Det er bra.

Styret i det norske globale fond mot aids, tuberkulose og malaria har definert disse tre som «fattigdomsrelaterte sykdommer» (6). Pengestøtten i de to globale programmene til Forskningsrådet ser ut til å være begrenset til disse tre sykdommene. Også GAVI

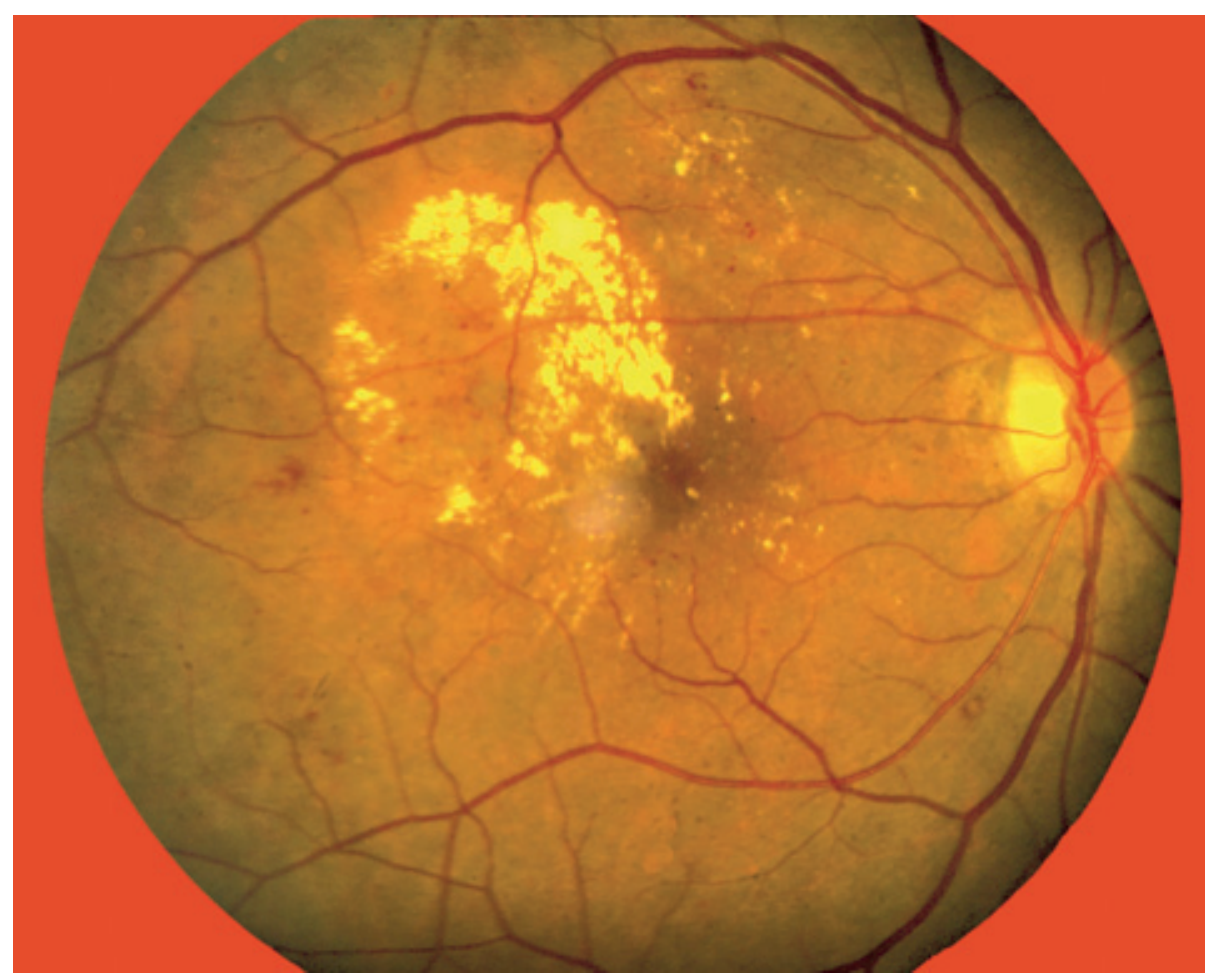

Retinopati er en av flere kjente komplikasjoner ved diabetes. Foto Photo Take/GvPress/NordicPhotos 